$\xi=-1$

\title{
Halal Cosmetic Products: Do Knowledge and Religiosity Affect Consumers' Attitude and Intention to Use?
}

\author{
Norazah Mohd Suki ${ }^{1}$, Norbayah Mohd Suki \\ ${ }^{1}$ Labuan Faculty of International Finance, Universiti Malaysia Sabah, 87000 F.T. Labuan, Malaysia \\ ${ }^{2}$ Faculty of Computing and Informatics, Universiti Malaysia Sabah, 87000 F.T. Labuan, Malaysia
}

\begin{abstract}
The goal of this research is to examine the effect of knowledge and religiosity on consumers' attitude towards Halal cosmetic products. Furthermore, the influence between consumers' attitude and their intention to use Halal cosmetic products is also explored. The Partial Least Square-Structural Equation Modelling (PLS-SEM) approach supported by Smart-PLS 2.0 was employed to evaluate the hypothesized model. This study conveys a strong message to cosmetic companies, particularly the producers, retailers, and distributors of cosmetic products regarding the imperative to foster better knowledge among consumers' regarding Halal cosmetic products consumption. The path estimate results of the PLS-SEM approach revealed that attitude is the strongest predictor of consumers' intention to use Halal cosmetic products. By having a positive attitude towards Halal cosmetic products, consumers' always look for the Halal label when buying cosmetic products. This proposition is further strengthened when the people considered most important to them also use Halal cosmetic products. Further, it was revealed that they also hold a strong belief that using Halal cosmetic products is important to them, especially when the decision to use it is of their own choice. Further, consumers' attitude towards Halal cosmetic products was impacted by aspects such as knowledge and religiosity. This study also informs on the benefits of fostering better knowledge among consumers' regarding Halal cosmetic products consumption towards captivating more demand of product consumption from Muslim consumers. The possible direction for future research is also presented.
\end{abstract}

Keywords: Knowledge, Religiosity, Attitude, Intention to use, Halal Cosmetic, Partial Least Square-Structural Equation Modelling (PLS-SEM)

\section{Introduction}

In the Quran, "Halal" is referred to as legal or allowed. All foods that are mentioned in the Quran are Halal, except those that are specifically mentioned as Haram, and banned1. Muslim consumers are thoughtful in their buying behavior to guarantee that the products they purchase are Halal (lawful) and toyyib (good) according to their religion. The Halal concept being used as part of a moral and belief code guides consumers' to purchase products and services.

Muslim consumers are faced with a wide selection of product and services that are provided in stores, including those of Halal and non-Halal products.

The Halal cosmetic market is on the rise globally. It has been reported that the sales value of cosmetic-related products is USD12 billion in the Middle East and there has also been an upsurge in demand in both Indonesia and Malaysia, as well as in European markets, as acknowledge by Elasrag2 and Rasid3. Local brands appear to capture their own market segment by projecting the products as Islamic brands through the type of packaging used and being categorized as Muslim products, thereby being attractive to consumers specifically seeking Halal products for their daily consumption4. Muslim consumers are highly concerned with product ingredients, which must be aligned with their closely held Muslim values5.

Arshia and Mohsin6 stressed that there is a limited amount of research related to the Halal cosmetics environment, which applied the theory of reasoned action (TRA) model, as more emphasis had been given to Halal food products. Henceforth, the goal of this research is to examine the effect of knowledge and religiosity on consumers' attitude towards Halal cosmetic products in order to provide the insight that is currently lacking in this areas of research. Furthermore, the influence between consumers' attitude and their intention to use Halal cosmetic products is also explored. This empirical research delivers significant input to producers, retailers, and distributors of cosmetic products in understanding specific factors that affect and influence consumers' attitude and intention towards Halal cosmetic products. The findings of this research will help them to increase demand for Halal cosmetic products among Muslim consumers.

The subsequent section presents a review of related literature, while section three elaborates on the methodology used to carry out the survey. Data analysis is detailed in Section four. The final section provides a conclusion, implications of the study, and direction for future research.

\section{Literature review}

The TRA model is a belief-attitude-behavioral intention model ${ }^{7}$. It has been applied to numerous fields. The theory postulates that intention, as the direct precursor to behavior, is derived by the individual's attitude and the subjective norms ${ }^{8}$. This study uses TRA model as the guiding principle.

Knowledge is referred to the facts, feelings or experiences known by a person or a group of people ${ }^{9}$. The results of preceding works by Bang et al. ${ }^{10}$ noted that knowledge affected consumer intention. Indeed, research scholars such as Abdul Aziz and Chok ${ }^{11}$ found that knowledge affected consumers' attitude towards Halal foods. 
The aspects of 'Halalness' knowledge of the products is very important during decision making, either to accept or reject a product $^{12}$. However, this significant finding is contrary to the work of scholar like Hamdan et al. ${ }^{13}$ who concluded that the impact of this factor on purchasing decisions is weak. Consumers have sound knowledge on the concept of Halal, but they still have low awareness regarding Halal certification and Halal label ${ }^{14}$. However, knowledge was influenced by the level of understanding gained from information that revealed more details about Halal products ${ }^{15}$ Knowledge contributes to consumers' buying behavior, product information searches, and product evaluations ${ }^{16-18}$. Based on this reasoning, the following hypothesis was posited:

H1: Knowledge has a positive effect on consumers' attitude towards Halal cosmetic products

Religiosity is "the extent to which an individual is committed to his religion, where it is then imitated in his/her attitude and behaviour" 19 . Religion can be considered as an essential element in an individual's decision making process. Muslim consumers gain appropriate knowledge by putting more trust in information received from eligible sources, which are derived from reliable authorities or religious leaders. However, cosmetic products are largely produced by non-Muslim manufactures and distributed from non-Muslim countries. Therefore, Muslim consumers nevertheless have doubts about the ingredients in these cosmetic products, whether described as Halal or non-Halal. Earlier research found that there is a correlation between a consumer's religious affiliation and a number of consumption-related variables ${ }^{20}$. Further, religion affected consumers' food choices and food consumption ${ }^{21-22}$. Consequently, the ensuing hypothesis postulates that:

H2: Religiosity has a positive effect on consumers' attitude towards Halal cosmetic products

Attitude toward the behavior is referred as the "degree to which a person has a favorable or unfavorable evaluation of the behavior in question" ${ }^{23}$. Attitude also relates to an individual's judgment and perceived consequences whether the act on a specific behavior is good or bad ${ }^{24}$. A study by Briliana and Mursito ${ }^{25}$ discovered that attitude is the most significant predictor of behavioral intention. In tandem to this result, Azmawani et al. ${ }^{9}$, and Hinsz and Nickell ${ }^{26}$ declared that when consumers' attitude is positive, their behavioral intentions also tend to be positive. Consequently, based on the aforesaid literature, it was hypothesized that:

H3: Consumers' attitude has a positive effect on consumers' intention to use Halal cosmetic products

Based on the above-mentioned literature, Figure 1 outlines the proposed theoretical framework of the present study.

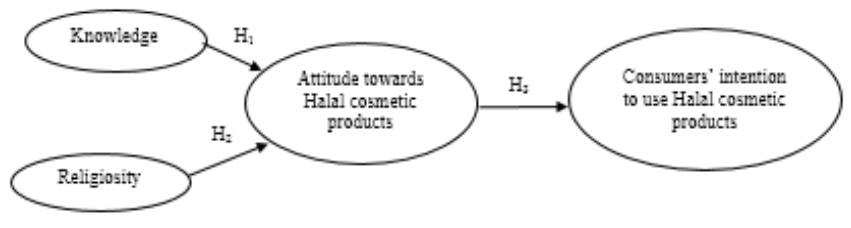

Figure 1: Proposed Theoretical Framework

\section{Methodology}

A structured self-administered questionnaire was distributed among 350 students in a public higher learning institution in the Federal Territory of Labuan, Malaysia. After eliminating those questionnaires that had not been filled-up appropriately, 300 usable responses were captured for further analysis with a valid response rate of $86 \%$. Section A of the two-section questionnaire covered socio-demographic characteristics of the respondents, such as gender, age, sources of information received regarding Halal cosmetic, and payment method when purchasing Halal cosmetic. Section B of the questionnaire enclosed twenty measure- ment items, which were measured on five-point Likert scales stretching from 1 (strongly disagree) to 5 (strongly agree).

The measurement items were derived from four factors namely knowledge (5 items) were adapted from Golnaz et al. ${ }^{27}$, religiosity (5 items) were modified from several sources studies ${ }^{1,28-29}$, attitude towards Halal cosmetic products (5 items) and intention to use Halal cosmetic (5 items) were borrowed from Aziz et al. ${ }^{30}$, and Salman and Siddiqui ${ }^{29}$. A Partial Least Square-Structural Equation Modelling (PLS-SEM) approach supported by Smart-PLS 2.0 was employed to evaluate (i) the effect of knowledge and religiosity on consumers' attitude towards Halal cosmetic products, and (ii) the influence between consumers' attitude and their intention to use Halal cosmetic products.

\section{Data analysis}

Table 1 displays the frequency distribution of the respondents' socio-demographic profiles. Of 300 students involved in the study, female respondents provided more participations than male respondents (57:43). More than three-quarter of the respondents $(80 \%)$ were aged less than 22 years old. When asked about sources of information received regarding Halal cosmetic, respondents reported advertisements and friends were the top two leading sources. Further, they mainly used online banking as the most preferred payment method when purchasing Halal cosmetic, followed by debit card.

\subsection{Partial Least Square-Structural Equation Modelling}

PLS-SEM was executed via a two-stage analysis of data: measurement model and structural model. The measurement model was inspected on the basis of internal consistency reliability, convergent validity and discriminant validity of the measurement items. The reliability of each construct was checked via Cronbach's alpha and composite reliability. The results of Cronbach's alpha and composite reliability for the study conducted were greater than 0.70 , signifying concrete reliability among the constructs.

Table 1: Socio-demographic profile of respondents

\begin{tabular}{|c|c|c|c|}
\hline Variable & & Frequency & Percentage \\
\hline \multirow[t]{2}{*}{ Gender } & Male & 129 & 43.0 \\
\hline & Fenale & 171 & 57.0 \\
\hline \multirow[t]{4}{*}{ Age (years old) } & & 31 & 10.3 \\
\hline & $20-22$ & 210 & 70.0 \\
\hline & $26-28$ & 30 & ${ }_{23}^{10.7}$ \\
\hline & $29-31$ & 2 & 0.7 \\
\hline \multirow[t]{4}{*}{ Sources of information received regarding halal cosmetic } & Friends & 113 & 37.7 \\
\hline & Magazine & 33 & 11.0 \\
\hline & E, hibition & 27 & 9.0 \\
\hline & Advertisement & 127 & 42.3 \\
\hline \multirow[t]{5}{*}{ Payment method when purchasing halal cosmetic } & Online barking & 258 & 86.0 \\
\hline & Debit card & 19 & 6.3 \\
\hline & Credit card & ii & 3.7 \\
\hline & Cheque & 2 & 0.7 \\
\hline & Cash on delivery & 10 & 3.3 \\
\hline
\end{tabular}

The convergent validity of the measurement items was evaluated by referring to the values of item loadings and average variance extracted (AVE). Earlier research noted that convergent validity is reached when the factor item loadings were beyond $0.70^{31}$ and AVE values exceeded $0.50^{32}$. In this study, all factor item loadings bested 0.70 and AVE values were more than 0.50 , implying that convergent validity was attained.

Discriminant validity was assessed by comparing the shared variance between variables with the square root of the AVE of each variable $^{32}$. A reasonable discriminant validity is considered present when the latter is bigger than the former. The shared variance between variables was lower than the square root of the AVE of each variable, ratifying the discriminant validity (see Table 2). Further, all correlation coefficients were below 0.70 , preserving an adequate discriminant validity and multicollinearity was vague in this research ${ }^{33-35}$. 
Table 2: Inter Construct Correlation

\begin{tabular}{|c|c|c|c|c|}
\hline Variables & 1 & 2 & 3 & 4 \\
\hline (1) Knowledige & 0.795 & & & \\
\hline (2) Religiosity & $0.590 * *$ & 0.826 & & \\
\hline (3) Attitude towards Halal cosmetic products & $0.462 * *$ & $0.472 * *$ & 0.875 & \\
\hline (4) Intention to use Halal cosmetic & $0.598 * *$ & $0.660^{* *}$ & $0.583 * *$ & 0.870 \\
\hline Mean & 4.066 & 3.880 & 4.163 & 3.829 \\
\hline Standard deviation & 0.814 & 1.026 & 1.358 & 1.009 \\
\hline Skeruphes & -0.725 & 0.825 & 3.386 & -1.055 \\
\hline Kurtosis & 2.893 & 12.682 & 27.491 & 0.194 \\
\hline
\end{tabular}

bold are the square root of the average variance extracted.

The structural model was executed to inspect the effect between independent variables and dependent variables in the research model. Table 3 itemizes the results of the standardized path coefficient and $t$-tests of the structural model by employing a bootstrapping resampling technique with 500 sub-samples.

Table 3: Statistical Results of the Structural Model

\begin{tabular}{|c|c|c|c|c|}
\hline Paths & $\begin{array}{c}\text { Path } \\
\text { Coefficients }\end{array}$ & $\begin{array}{l}\text { Standard } \\
\text { Brror }\end{array}$ & t-value & Results \\
\hline H. Knowledge --> Attitude & 0.258 & 0.069 & 3.747 & Supported \\
\hline H2 Religiosity -.-> Attitude & 0.590 & 0.062 & 9.476 & Supported \\
\hline H3 Attitude $\rightarrow>$ Intention to use & 0.826 & 0.028 & 29.334 & Supported \\
\hline
\end{tabular}

More specifically, knowledge significantly and positively affected consumers' attitude towards Halal cosmetic products $\left(\beta_{1}=0.258 t\right.$ value $=3.747, p<0.05$ ), as posited in H1. Therefore, H1 was supported, which was within expectations. In a similar vein, $\mathrm{H} 2$ was retained. Empirically, the standardized beta for religiosity was 0.590 with $t$-value of 9.476 and $p<0.05$. These findings infer that religiosity has a significant impact on consumers' attitude towards Halal cosmetic products. Further inspection of the PLS-SEM path coefficients revealed that support was very strong for H3, which suggested that attitude influenced consumers' intention to use Halal cosmetic products $\left(\beta_{3}=0.826, t\right.$-value $\left.=29.334, p<0.05\right)$. Therefore, $\mathrm{H} 3$ is retained. The total variance of each endogenous construct explained by the model is $63 \%$ for consumers' attitude towards Halal cosmetic products and $68 \%$ for consumers' intention to use Halal cosmetic products, thereby attesting the model's predictive validity.

\section{Discussion}

This study examined the effect of knowledge and religiosity on consumers' attitude towards Halal cosmetic products. Additionally, the influence between consumers' attitude and their intention to use Halal cosmetic products was also explored. As expected, knowledge was found to impact consumers' attitude towards Halal cosmetic products, which supports $\mathrm{H} 1$. These results pointed out that knowledge consumers exhibit a strong tendency to opt for Halal cosmetic products as they developed a positive attitude towards Halal cosmetic products. The rationale was that they have sufficient knowledge to differentiate between permissible and forbidden ingredients, besides a sound understanding regarding the Islamic law of Halal and Haram for cosmetic products. Most importantly, they have abundant knowledge of which cosmetics are forbidden by Islam as they are well informed about the current issues regarding product ingredients. In particular, they are also able to differentiate between Halal certification for products and Halal certification for premises, while looking for Halal cosmetic products. This result is comparable with the majority of foregoing studies $^{11,16-18}$ which report that a positive influence exists between knowledge and consumers' attitude.

In addition, the PLS-SEM results reveal that religiosity had a significant impact on consumers' attitude towards Halal cosmetic products, which supports $\mathrm{H} 2$, and signifies that an increase in religiosity would increase the consumers' attitude towards Halal cosmetic products. Their level of religiosity is amplified when they continuously pay zakat on time and enjoy spending time with other people from similar religious affiliation. They also actively attend religious talks at mosque, and read religious books and magazines, as well as watch religious programmes on TV. This religiosity exposure stirs up consumers' interest to purchase cosmetic products with a trustworthy Halal logo and certification. This significant finding is coherent with the result of a prior works of Bonne et al. ${ }^{21}$, and Megawati and Muhammad ${ }^{22}$ who confirmed that consumers' attitude improves when the level of religiosity is intensified.

Further assessment of the path estimate results of the PLS-SEM approach revealed that attitude is the strongest determinant of consumers' intention to use Halal cosmetic products. H3 was thereby supported, as hypothesized. This result was analogous with the results of previous work of Azmawani et al. ${ }^{9}$, and Hinsz and Nickell ${ }^{26}$. By having positive attitude towards Halal cosmetic products, consumers' always look for the Halal label when buying cosmetic products. This is further strengthened when the people who are important to them also use Halal cosmetic products. They also exhibit a strong belief that using Halal cosmetic products is important to them and the decision to use them is of their own choice.

\section{Conclusion}

This study delivers some practical implications. This study conveys a strong message to cosmetic companies, particularly the producers, retailers, and distributors of cosmetic products concerning the need to foster better knowledge among consumers' regarding Halal cosmetic product consumption. In order to generate increased product demand from Muslim consumers, it is imperative for producers to clearly display Halal product ingredients on the cosmetic products packaging. Producers also need to strictly adhere to Islamic laws and Muslim values in their marketing efforts, including advertising their products. They need to employ credible celebrities or models in their marketing campaigns that have a high level of religiosity in using Halal cosmetic products. Further, producers, retailers, and distributors of cosmetic products need to be sensitive to the demands of the Muslim market by clearly presenting the authentic Halal logo certification onto the packaging of the cosmetic products to satisfy Muslim consumers' buying behavior.

In regards to the implications of this study from a theoretical perspective, the present findings advance the body of knowledge in terms of applying the TRA model in assessing the effect of knowledge and religiosity on consumers' attitude towards Halal cosmetic products. Empirically, attitude had the strongest impact on consumers' intention to use Halal cosmetic products. Future research is suggested to extend the present research framework by incorporating moderating variable such as gender in order to have widen acumen between male and female respondents. Further, enlargement of sample size would improve the generalizability of the current findings.

\section{References}

[1] SS Alam, NM Sayuti. Applying the theory of planned behavior (TPB) in halal food purchasing. International Journal of Commerce and Management, 21(1) (2011) 8-20.

[2] H Elasrag. Halal Industry: Key challenges and opportunities, Munich personal RePec archive (MPRA). Paper No.69631 (2016).

[3] AH Rasid. Global halal market growing bigger. New straits times online. Friday, 23 September 2016 (2016).

[4] A Mukhtar, MM Butt. Intention to choose Halal products: The role of religiosity. Journal of Islamic Marketing 3(2) (2012) 108-120.

[5] D Patton. Could halal cosmetics be developing into a new global C and $\mathrm{T}$ niche market? Available at: www.cosmeticsbusiness.com/story.asp?storyCode3706 (accessed 26 May 2013) (2009).

[6] M Arshia, M Mohsin. Intention to choose halal products: The role of religiosity. Journal of Islamic Marketing, 3(2) (2012) 1-11. 
[7] M Fishbein, I Ajzen. Belief, Attitude, Intention, and Behavior: an Introduction to Theory and Research, Addison-Wesley Pub., Co, Boston, MA (1975).

[8] RG Netemeyer, JC Andrews, S Durvasula. A Comparison of Three Behavioral Intention Models: the Case of Valentine's Day GiftGiving. In NA - Advances in Consumer Research Volume 20, eds. Leigh McAlister and Michael L. Rothschild, Provo, UT: Association for Consumer Research, Pages: 135-141 (1993).

[9] A Azmawani, A Ebrahim, A Suhaimi. Consumer and Halal cosmetic products: Knowledge, religiousity, attitude and intention. Journal of Islamic Marketing, 6(1) (2015) 148-163.

[10] HK Bang, AE Ellinger, J Hadjimarcou, PA Traichal. Consumer concern, knowledge, belief, and attitude toward renewable energy: An application of the reasoned action theory. Psychology and Marketing, 17(6) (2000) 449-468.

[11] Y Abdul Aziz, NV Chok. The role of Halal awareness, Halal certification, and marketing components in determining Halal purchase intention among non-Muslims in Malaysia: A structural equation modeling approach. Journal of International Food and Agribusiness Marketing, 25(1) (2013) 1-23.

[12] J Ireland, SA Rajabzadeh. UAE consumer concerns about halal products. Journal of Islamic Marketing, 2(3) (2011) 274-283.

[13] H Hamdan, ZM Issa, N Abu, K Jusoff. Purchasing decisions among Muslim consumers of processed halal food products. Journal of Food Products Marketing, 19(1) (2013) 54-61.

[14] S Rajagopal, S Ramanan, R Visvanathan, S Satapathy. Halal certification: Implication for marketers in UAE. Journal of Islamic Marketing, 2(2) (2011) 138-153.

[15] AH Rahman, WI Ahmad, MY Mohamaad, Z Ismail. Knowledge on halal food among food industry entrepreneur in Malaysia. Journal of Asia Social Science, 7(12) (2011) 216-221.

[16] JM Aertsens. The influence of subjective and objective knowledge on attitude, motivations and consumption of organic food. British Food Journal, 113(11) (2011) 1353-1378.

[17] A Gracia. Organic food product purchase behaviour: A pilot study for urban consumers in the South of Italy", Spanish Journal of Agricultural Research, 5(4) (2007) 439-451.

[18] DJ Stobbelaar, G Casimir, J Borghuis, I Marks, L Meijer, S Zebeda. Adolescents' attitudes towards organic food: A survey of 15 to 16 year old school children. International Journal of Consumer Studies, 31(4) (2007) 349-356.

[19] AN Ahmad. Assessing knowledge and religiosity on consumer International Journal of Social Science and Humanity, 6(11) (2015) 10-14.

[20] K Swimberghe, D Sharma, L Flurry. An exploratory investigation of the consumer religious commitment and its influence on store loyalty and consumer complaint intentions. Journal of Consumer Marketing, 26(5) (2009) 340-347.

[21] K Bonne, I Vermeir, F Bergeaud-Blackler, W Verbeke. Determinants of Halal meat consumption in France. British Food Journal, 109(5 (2007) 367-386.

[22] S Megawati, DM Muhammad. The effects of knowledge, religiosity value, and attitude on halal label reading behavior of undergraduate students. Asean Marketing Journal, 1(2) (2014) 65-67.

[23] I Ajzen. The theory of planned behavior. Organizational Behavior and Human Decision Processes, 50(2) (1991) 179-211.

[24] EN Untaru, A Ispas, AN Candrea, M Luca, G Epuran. Predictors of individuals' intention to conserve water in a lodging context: The application of an extended Theory of Reasoned Action. International Journal of Hospitality Management, 59(2016) (2016) 50-59.

[25] V Briliana, N Mursito. Exploring antecedents and consequences of Indonesian Muslim youths' attitude towards halal cosmetic products: A case study in Jakarta. Asia Pacific Management Review, 22(2017) (2017) 176-184.

[26] VB Hinsz, GS Nickell. The prediction of workers' food safety intentions and behavior with job attitudes and the reasoned action approach. Revista de Psicología del Trabajo y de las Organizaciones, 31(2) (2015) 91-100.

[27] R Golnaz, M Zainalabidin, S Mad Nasir, F Eddie Chiew. NonMuslims awareness of Halal principles and related food products in Malaysia. International Food Research Journal, 17 (2010) 667-674.

[28] AU Rehman, MS Shabbir. The relationship between religiosity and new product adoption. Journal of Islamic Marketing, 1(1) (2010) 63 69.

[29] F Salman, K Siddiqui. An exploratory study for measuring consumers awareness and perceptions towards halal food in Pakistan. Interdisciplinary Journal of Contemporary Research in Business, 3(2) (2011) 639-649.
[30] A Aziz, M Amin, Z Isa. The perception to choose halal cosmetics products: An empirical study for Malaysian consumers. available at: http://icbme.yasar.edu.tr/previous_conferences/2010/eproceeding/Azmi_AbdAziz.pdf (2010).

[31] JF Hair, B Black, B Babin, RE Anderson, RL Tatham. Multivariate Data Analysis: A Global Perspective. New Jersey: Pearson Education Inc. (2010).

[32] C Fornell, DF Larcker. Evaluating structural equation models with unobservable variables and measurement error. Journal of Marketing Research, 18(1) (1981) 39-50.

[33] J Pallant. SPSS Survival Manual: A Step by Step Guide to Data Analysis Using SPSS for Windows (3rd ed.). Maidenhead: Open University Press (2007).

[34] S Sussman, W Siegal. Informational influence in organizations: an integrated approach to knowledge adoption. Information Systems Research, 14(1) (2003) 47-65.

[35] BG Tabachnick, LS Fidell. Using Multivariate Statistics (5th ed.). Boston: Pearson/Allyn \& Bacon (2007). 